\title{
Analysis of Israelis [Jews and Arab-Palestinians]: exploring law in society and society in law
}

\author{
Gad Barzilai"
}

\begin{abstract}
Attributing a great deal of attention to global and local knowledge, this paper is focused on law and society scholarship that has been published by Israelis, both Jewish and Arab-Palestinians. It attempts to unveil and to map some of the major issues that have characterised the scholarly debates and intellectual discourse, primarily critical questions on law and political power, the nation-state, legal rights discourse and equality. More specifically, the paper analyses socio-legal research on various local issues, such as multiculturalism and national rifts on the backdrop of the 1967 military occupation alongside the emergence of a neoliberal capitalist economy. The protracted ArabPalestinian-Israeli conflict and the fragmentation of the political partisan map in Israel have incited more emphasis on the place of the Israeli Supreme Court, primarily sitting as a High Court of Justice, in public life as an important regulatory institution. This focus on the judicial power of the Court has resulted in an even more frantic controversy on whether the Court has become too engaged in political affairs. In all the law and society debates, local concepts and global knowledge have been intertwined. Hence, the paper enables scholars around the world to closely examine law and society scholarship on the convergence of local and global knowledge.
\end{abstract}

\section{Prologue of setting the stage}

This paper aims to offer an in-depth outlook into the academic research that scholars in Israel have produced on law and society. Based on analysis of hundred of studies on law and society written by Israelis that have been published since the I950s, in Hebrew, Arabic and English, it unveils the fruitful scholarship of Israelis as articulation, construction and generation of conflicts around the meaning of the nation-state and its relations with various segments of society from ruling elites to marginalised communities. I have preferred not to analyse the genealogy of studies on law and society along recognisable lines of theory vs. empiricism or positivism and formalism vs. realism. Rather, the paper endeavours to unveil how scholarship on law and society resonates with struggles around division of political power, defining and redefining the nation-state, and contradictory expectations of construction and reconstruction of public policies.

These struggles and conflicts of identities have formed and shaped distinctive types of research questions, theories and methodologies, which cannot exclusively be explained as an upshot of academic training; rather, scholars have been affected through a range of visions and concepts of the nation-state. Furthermore, to explore scholarship only based on affiliations with identity groups will not suffice. This paper aims to unveil a more compound map of research that looks mainly into the origins of how various scholars view the nation-state, and the ways in which local and global types of knowledge have converged to formulate interactions of research with social forces through law.

* Professor of Law, Political Science and International Studies and Dean of the University of Haifa Faculty of Law, and Emeritus Professor at the University of Washington. Email: gbarzilai@univ.haifa.ac.il. I would like to express my many thanks to David Nelken, Marc Hertogh and the external reader, whose comments have improved the paper. The responsibility is all mine. 
Readers may justly ponder the purpose of drilling into a local knowledge regarding law and society. One may erroneously presuppose that the meaning of local knowledge is nothing more than usage of generic terms in law and society scholarship in the context of a single country, like Israel. As shall be demonstrated below, Israeli scholars have indeed produced critical questions that have not merely a local meaning but which do entail broader ramifications on our understanding of research. However, the paper does not pretend to cover all dilemmas and questions raised in law and society scholarship published on Israel; rather, it will address some major issues under hectic intellectual deliberations and analyse the rise of critical legal scholarship on Israel published by Israelis.

\section{What is law?}

For Israeli scholars, the quandary of what is 'law' has been embedded from the outset in the challenge of establishing the nation-state in I948. Prominent academics of law and society were active members of political parties and were involved in what Barzilai and Peleg have coined 'constitutional engineering' of the newly born state (Barzilai and Peleg, 2009). As with other post-colonial countries, like India, Israel had inherited a colonial system of laws - the British Mandatary legalistic setting, and to a lesser extent the Ottoman system of law (Shamir, 2000; Likhovsky, I998).

Yet, as in other post-colonial states, the formation and codification of national state law, somewhat immersed in a colonial past, and yet aspiring to articulate and mould a newly born independence, was at stake. At this point, scholars of law and society were involved in debating the necessity of a written constitution and the possible need for a comprehensive legal codification. Since, in the early I950s, the community of law and society scholars in Israel was very small, the debates were limited in scope and dealt primarily with 'constitutional engineering' (Barzilai and Peleg, 2009).

Thus, in the I950s and I960s, renowned scholars such as Benjamin Akzin (I965, I966, I968) and Hans Klinghoffer (I963) were engaged in debates around the drafting of a written constitution. They presumed that state law was autonomous to politics and society, a professional and formal field that may structure, legalise and regulate public life. Akzin, a professor of political science and constitutional law at the Hebrew University of Jerusalem, was influenced by the positivist philosopher of jurisprudence Hans Kelsen. Accordingly, he argued for the enactment of a formal, hierarchical set of constitutional norms that would codify the essentials of a democratic political regime in Israel. Klinghoffer, also a professor of law at the Hebrew University, was engaged in administrative law and its ability to engender constitutional order. Both Akzin and Klinghoffer were affiliated with the political opposition, aspiring to restrain the political power of the then dominant ruling party, Mapai. ${ }^{\mathrm{I}}$ Akzin was an active Revisionist during the pre-state era, and served as the secretary of Revisionism's ${ }^{2}$ founding father, Ze'ev Jabotinsky. Klinghoffer was a member of the General Zionists, ${ }^{3}$ and later its active Member of Knesset (Israeli parliament). As students of continental Austrian-German concepts of law, both of them believed in a strong cohesive state law as an effective instrument in the establishment of an independent civic mechanism of separation of powers and entrenchment of civil rights (Barzilai and Peleg, 2009).

I Mapai was the main political party in the Labor political camp, and the dominant political party in Israel until the I960s. Then it became the major political block in the Labor Party that was the ruling political party in Israel until 1977.

2 The Revisionist movement was the right-wing political camp in Israel and the basis for the right-wing political party of Herut, which became the main pillar in the ruling party of Likud after 1977.

3 The General Zionists were relatively right-wing liberals who joined Herut in I965. 
This jurisprudential concept was further enunciated by a second generation of scholars of constitutional and administrative law such as Aharon Barak (I998, 2004, 2006) and Itzhak Zamir (I993a, I993b; Zamir, Rubinstein and Guy-Ron, 200I), both former deans of the Hebrew University Faculty of Law, and later Supreme Court Justices, as well as other scholars, most prominently Amnon Rubinstein (I969) and Amos Shapira (1983, I993; Shapira and Bracha, I972), deans of Tel Aviv University Faculty of Law. These scholars were interested in developing a codified Israeli law as a structured autonomous professional field, which would transcendently form and monitor political order (Barzilai and Peleg, 2009).

While the first generation represented by Akzin and Klinghoffer was robustly familiar with theories of political regimes, the second generation was mainly preoccupied with systematically framing and organising systems of administrative and constitutional law. They assigned particular importance to legalistic rules of the political game, the norms of legal interpretation, the establishment of administrative tribunals, the effectiveness of the judiciary - especially the Supreme Court - and the construction of constitutional law that would ensure governability and civil rights. The 1967 occupation of the Palestinian territories was considered a challenge to democratic law, but temporary in essence. The emphasis was not on critically examining firstorder issues of national ideology, its legalistic reproduction, and political power, but rather the emphasis was on second-order issues of legal construction and interpretation (Barzilai and Peleg, 2009).

Both generations of scholars aspired to employ law as a system to establish and maintain the democratic Jewish nation-state, with an emphasis on constitutionally defining its fundamentals and constructing its various aspects of private, public, civil and criminal law.

Gradually, however, the main issues unveiled by law and society scholars have shifted from formalistic legalistic constructions of the Israeli Jewish republic into analysing the possible contradictions in its definitions as a nation-state, examining the ramifications of those contradictions on state and society relations and on minority-majority interactions. The sections below deal with efforts of Israeli law and society scholars to respond to and to explicate aspects of law and society relations and to critically use law and society concepts to better deconstruct state law.

\section{A Jewish and democratic state}

The statutory legalistic definition of Israel as a 'Jewish and Democratic state' dates back to I 985 , when Clause 7 A(a)(I) to Basic Law: The Knesset was enacted, and since then Basic Law: Human Dignity and Freedom (Clause IA), and Basic Law: Freedom of Vocation (Clause 2), were enacted in I992 and I994, respectively. Yet public and constitutional controversies among scholars of law and society regarding the nation-state's desirable constitutional definition had already been aired, primarily since the beginning of the I980s, when students of law and society were concerned with the possible contradictions between the democratic facets of the nation-state and its ethno-national aspirations as a centre of Jewish nationalism.

The controversies have primarily been aired around three main issues: separation of state from religion and freedom of religion; non-Jewish minorities, mostly Arab-Palestinians facing Jewish ethno-nationalism, and democracy; and possible contradictions between the aspirations of a 'Jewish and democratic state' and the I 967 military occupation. Let us elaborate on each of these categories.

\subsection{State and religion}

The first debate among jurists and law and society experts has been focused on the effects of Orthodox Judaism that has never been constitutionally separated from the nation-state in Israel public life, and its ramifications on the Israeli rule of law. Mainly Zionist religious scholars have underscored that, 
with the exception of religious Halachik law in Rabbinical courts, Orthodox Jewish religious values are absent in legal interpretations, and they should be reinforced through legislation and legal interpretations (Statman and Sapir, 20I4). Yet the most vocal voice in that respect has been Supreme Court Justice Menachem Alon, who has ruled in various courts that ignorance of the judiciary from Orthodox Jewish values in legal hermeneutics stands in contradiction to Basic Law: Fundamentals of Law (I980), which allows judges to refer to Halachik law in legal interpretations (Alon, I973, Mautner, 2008).

Furthermore, Alon has argued in his academic research and writings that contemporary legal interpretations of the Basic Law: Fundamentals of Law are purposely and regretfully neglecting the usage of Halachik Jewish sources as Biblical, Talmudic and Rabbinical legal texts (Mautner, 2008). Conversely, Chief Justice Aharon Barak, like several law and society scholars, has consistently articulated the opposite view and underscored the need to render and develop legal interpretations based on a secular, liberal outlook (Barak, 2006; Gavison, I999a, I999b; Mautner, 2008). Similarly, liberal Zionist religious Jews have argued that balancing the values of Israel as a Jewish state with liberal values may encourage more inclusion and liberalisation of religious services (Statman and Sapir, 2014; Stern and Ravitzki, 2007). One important issue that has been debated in this context is marriage and divorce.

Israel state law has not recognised civil marriage and divorce nor allowed civil jurisdiction in this matter. All legal registered marriage and divorce cases are subjected to religious Orthodox law based on the religious faith and religious-national affiliations of the relevant couples. Thus, Halachik law has been applied to Jews, Shari'a law to Muslims, canonical law to Christians, Druze religious texts to Druze, etc. Each ethno-national religious community has had its relevant religious judicial system recognised by state law, which also manages judicial nominations to those respective religious courts. Rulings of the religious courts have been subjected to the possibility of appeals to the High Court of Justice (HCJ), which has been inclined to intervene and reverse those rulings only very rarely in relatively few legal cases of a judicial mistake that has distorted the Court's decision.

As legal realism and critical scholarship of law have taught us (Fisher and Horwitz, I993), scholars have to drill into the discrepancies and contradictions between law in life and law in the books, and study the socio-economic essence of the rule of law. While the national legal regime is of Orthodox religious marriage and divorce, the majority of the Israeli public is secular or nonOrthodox, primarily among Jews and Arab-Christians. Accordingly, and especially with the liberalisation of legal culture after the I980s (Barzilai, 2003), there has been a rise in various forms of non-Orthodox marriage procedures (e.g. reformists and conservatives) and civil marriage forms conducted by Israeli Jews outside Israel, in countries like Cyprus and Paraguay. Furthermore, common-law marriages have become more prevalent, and the judiciary has acknowledged property rights of spouses (including homosexuals) who have lived in the framework of a common-law marriage (Statman and Sapir, 20I4). Hence, formal state law has constantly been challenged by civil non-Orthodox practices that have contextualised formal state law.

Both secular and religious scholars of law and society have been aware of it, and have intellectually challenged the legalistic status quo of Orthodox monopoly over marriage and divorce in order to adapt it to multicultural and practical legal pluralism in Israel. Thus, beside secular critical scholars who have called for complete separation between the nation-state and religion, liberal Zionist religious scholars have argued that, whilst Judaism is a dominant part of Zionism and embedded in Israel's national identity, two formal institutionalised channels of marriage and divorce should be established - Orthodox religious and civil (Statman and Sapir, 20I4).

This construction of dual institutional arrangements has reflected an increasing critique of state law, even among religious intellectuals. Yet it has reflected a rather limited critique of the basic nonseparation between Judaism, religious Orthodoxy, Zionist nationality and the nation-state (Barzilai, 
2003). Hence, legal writings drilling into such specific issues as Rabbinical courts and jurisdiction over marriage and divorce, even scholarship on the privatisation of religious services (Gavison, I999a, I999b), have intellectually blurred the connection between secondary religious arrangements and the institutionalisation of Jewish Orthodoxy in state power foci. Conversely, the critical perspective on law and society has considered the non-separation of Jewish Orthodoxy and the nation-state as subjugation of secular and non-Orthodox religious Jews to a legal regime that has excluded alternatives ways of life (Mautner, Sagie and Shamir, I998).

\subsection{Non-Jewish minorities}

Law and society scholars have been puzzled as to whether non-Jewish minorities might be empowered and get their legal rights in a nexus of a 'Jewish and democratic state'. The percentage of non-Jewish minorities in Israel seen a constant rise since the late I940s: about I5 per cent when Israel was established in I948, to about 25 per cent (including foreign workers) in 2014. Among the minorities that have constituted about 25 per cent of the country, roughly 75 per cent are Muslims (predominantly Sunni Muslims). Scholarship on law and society has analysed their legal status on three levels: individual rights, group affiliated rights, and their status as an integral part of the republican body politic (Peled, I992; Barzilai, 2003). Research has demonstrated that, amidst the development of more liberal jurisprudence, including in Supreme Court rulings (Dotan, 20I3; Mautner, 2008), most of the discrimination against Arab-Palestinians - Israeli citizens - might be unveiled at the collective (republican) level (Peled, I992; Rouhana, I997; Sultany, 20I2; Saban, 2002, 2004, 2005; Smooha, I990).

Thus, some scholars have underscored cases of discrimination against Israeli Arab-Palestinians as individual citizens, discrimination that may have been tightly connected to the structure of Israel as a Jewish state, albeit a democracy (Kretzmer, I990; Jabareen, 2000; Smooha, I990, I997, I999; Sultany, 20I2). The liberal presumption has been that litigation and legislation, even some statutory apparatus of affirmative action, may offer legalist remedies to such cases of unjust preferences given to Jews over Arab-Palestinians. The more Israel becomes a liberal democracy, the more its constitutional balance between Jewish and democratic values may affect the formation of an egalitarian public policy. Subsequently, less discrimination may be entailed against individuals, and correspondingly less police violence may be inflicted on Israeli Arab-Palestinians (Hasisi, 2006). The research and publications of advocates of liberal jurisprudence have alleged that the structure and fundamentals of a 'Jewish and democratic state' may allow the removal of cultural and institutional impediments that have halted equality between Arab and Jewish citizens of Israel (Gavison and Hacker, 2000).

Conversely, however, some law and society scholars have shifted the perspective from individual rights to group rights that are rendered to or kept from a cultural group as a collective vis-à-vis the Jewish nation-state (Barzilai, 2003; Shamir, I996; Sultany, 20I2; Jabareen, 2000). Israeli law has recognised some of those types of rights in legislation and court rulings. One type would be rights given to non-Jewish Christian communities to have communal schools subsidised by private funding. Muslim schools, on the other hand, are part of the national education system but have the right to shape a curriculum in Arabic and to have also Shari'a studies, yet are tightly supervised by the government (Al Haj, I995). In personal law, religious courts do enjoy jurisdiction, since the nation-state had already recognised a multiplicity of religious practices in 1948. Yet the nation-state has prevented, both in legislation and in court rulings, any constitutional recognition of Palestinian nationalism under the pre-1967 territories (Barzilai, 2003; Kedar, I998, 200I; Yiftachel, 2000; Saban, 2002, 2004, 2005).

Thus, Israeli law allows the government to cut about one-third of the national budget from any public institution that mentions the Palestinian Naqba (Law Fundamentals of Budget). The Supreme Court in its rulings has recognised the right of Israeli Arabs to have road signs in Arabic, but only as 
long as such a right is based on liberal jurisprudence of individual rights. Such reluctance of recognition of group rights, while not unique to Israel, has certainly incited criticism, mainly by Israeli Palestinian law and society scholars (Jabareen, 2000; Sultany, 20I2). The nation-state has prevented any constitutional recognition of legal rights that may endanger the ethnic-national hegemony of the Jewish majority (Al Haj, I995). Critical law and society scholars have shifted the intellectual gravity point from liberal jurisprudence as a balancing legalistic force between Judaism and democracy, arguing that liberal jurisprudence may increase individual equality among citizens but would enforce discrimination against Israeli Arab-Palestinians as a national minority that has challenged Jewish republicanism and ethno-nationalism (Barzilai, 2003; Kedar, I998, 200I; Yiftachel, 2000; Saban, 2002, 2004, 2005; Shamir, I996; Sultany, 2012; Jabareen, 2000; Peled, 1992).

The I 967 military occupation has been largely criticised by law and society scholars, both Jews and Arab-Palestinians. Yet its ramifications on democratic foundations have been viewed differently. Liberal students of law and society have emphasised that a constitutional balance between the democratic principles and ethno-national interests had somewhat been consolidated in pre-I967 Israel, however rift that reality might be. Yet maintenance of the 1967 military occupation, they have warned, may cause irreversible damage to Israel's pre-I967 democratic principles (Kretzmer, 2002; Kremnitzer, Kretzmer and Benish, 2002; Dotan, I999, 2013; Peleg, I995, 2004a, 2004b).

Critical observers of law and society's practices have pointed to additional process of both external and internal colonisation against Israeli Palestinians and Palestinians in the occupied territories, respectively, which may uproot democracy in Israel. Accordingly, while a constitutional balance between Jewish and democratic values, as articulated in the HCJ's rulings, may halt the prompt destruction of democratic fundamentals, it may veil ethno-nationalism as the main cause of danger to Israeli democracy. Hence, critical scholars of law and society (Barzilai, I998, 2003/2005; Kedar, I998, 200I; Shamir, I990, I994) have argued that legalistic criticism of specific court rulings and specific legislation are insufficient for attaining the constitutional democratic order of the Israeli setting. Rather, they have called for a structural reform that requires a constitutional separation between Israeli nationality and Judaism, and the transformation of ethno-religious nationality into liberal citizenship that is conferred based on residence, immigration and loyalty, but not on predetermined ethno-national affiliations (Peled, I992; Yiftachel, 2006).

The Law of Return (I950) that has been defined by the Israeli Supreme Court as fundamental legislation that embodies Israel's basic national values is an important point of controversy. ${ }^{4}$ On the one hand, research may point out that the Law of Return is necessary to form the criteria for citizenship in a country which is based on the absorption of immigrants (Carmi, 2003). About 60 per cent of Israel's population growth has been based on immigration. Furthermore, the Law of Return may be justified in a country that has been engaged in a war since 1948, amid salient Palestinian claims to return to lands confiscated during the I948 war. Yet especially Israeli ArabPalestinian scholars have argued that the Law of Return is discriminatory due to the absence of distinction between Judaism, nationality and citizenship, and hence it should be declared null and void (Jabareen, 2000; Sultany, 2012).

The controversy over the Law of Return has also been contentious as to whether a liberal democracy may generate ethno-nationalism, giving a preference to Jewish nationality. While some Jewish scholars have criticised it, the Law of Return has mainly been severely questioned by Israeli Palestinian scholars. They have considered it not only a legalistic means that disconnects Palestinians from their right to return, but also a symbolic setting that points to two types of citizens and discrimination against Israeli Arabs (Jabareen, 2000; Sultany, 20I2).

4 See, for example, HCJ I8/72 Shalit $v$. The Minister of Interior, 26 (I) 334; HCJ 6698/95 Kaadan v. The Israeli Land Administration, 54 (I) 258. 


\subsection{The 1967 military occupation}

Largely, the community of law and society scholars in Israel has opposed the I967 military occupation of the West Bank and has considered it as damaging to the fundamentals of Israeli democracy. Yet there has been a divide between liberals and critical scholars of law and society. The former have argued that the 'green line', the pre-1967 border between Israel and Jordan, is in practice and legally the borderline between a liberal democracy that respects human rights and civil rights, and a military regime over the 1967 occupied territories.

On the one hand, there is a political democratic regime that abolished martial rule over the ArabPalestinian minority in November 1966, and on the other hand, there is the post-1967 military rule over the West Bank, and the unilateral annexation of East Jerusalem and the Golan Heights, which may never end (Sheleff, I 996; Kreztmer, 2002). Liberal legal observers have marked the political space based on three main criteria: ordered legalistic democratic procedures, civil rights, and effective judicial review. Based on these criteria, Israel has been considered a divided political regime, within and outside the 'green line'. Thus, above the issue of military rule and the absence of civil rights, scholars have largely criticised the lack of effective judicial review by the HCJ over the deeds of the military and the security forces in the 1967 occupied territories (Shamir, I990; Hofnung, I996; Peleg, 2004b; Kretzmer, 2002). The more the Supreme Court has become engaged in political affairs, and the more the Israeli academia has been touched by US-led intellectual focus on the judiciary, the more such a scholarly criticism of the HCJ has been aired (Dotan, 20I3; Gavison, Kremnitzer and Dotan, I990; Hirschl, 1997).

In a small country where the HCJ has dealt every year with about 4,00o legal cases - and in total the Supreme Court has annually decided on about I4,000 legal cases - the expectations of the Supreme Court have been enormous (Barzilai, Segal and Yuchtman-Yaar, I994). Yet only rarely the Court has decided to uphold an appeal that rules on the illegality of the occupation (Kretzmer, 2002). For liberals who have been educated to believe in the power of judicial review and to have faith in its contribution to the liberal process, the relative judicial passivity of the Supreme Court has caused grave concern.

On the other hand, critical observers of law and society in Israel have viewed it differently. The mere fact that the Supreme Court had decided in the early I970s to impose its judicial review on the occupied territories has been considered negatively; primarily but not exclusively by Israeli ArabPalestinian scholars (Sultany, 20I2; Jabareen, 2000). They have regarded the Supreme Court as a Jewish institution - with only one Arab-Palestinian judge, a state's agent of the larger structure of the Jewish nation-state that has activated its judicial agent to legalise and legitimate the I967 military occupation - as if it has been subjected to a transparent, professional and fair judicial review (Shamir, I996). More generally, critical scholars have underscored a broader context of colonisation, whereby the Jewish-Zionist elite has expelled Arab-Palestinians from their lands within the 1948 borders, confiscated lands, and prevented Arab-Palestinians (including the Bedouin) from returning to their lands. From that perspective, the I967 occupation has only been an epiphenomenon of the ethno-national conflict and the structured exclusion of ArabPalestinians from their national and land rights (Kedar, I998, 200I; Yiftachel, 2000; Saban, 2002, 2004, 2005; Shamir, I996; Sultany, 20I2; Jabareen, 2000; Peled, I992).

\section{Social equality}

\subsection{Making law more accessible}

With the emergence of the politics of identities in various campuses around the Western world, and an increasing number of Israeli scholars who graduated in liberal US law and social sciences or humanities graduate schools, being hired by Israeli universities, research aimed at a socio- 
economic, cultural and political deconstruction of law began to significantly emerge in Israel after the I980s. Those scholars were trained less in the formalistic reading of law and more in a realist and critical intellectual environment, and were educated in the interdisciplinary deconstruction of law. Thus, more and more research has been published since the early I 990 os on law and social equality.

The 1967 military occupation, accompanied by the predicament of Israeli Arab-Palestinians and rising socio-economic stratification in Israeli society, have incited the legal deconstruction of the state's legal ideology, judicial policy and court rulings, and its veiled sociopolitical and economic interests. Correspondingly, formalistic analysis of state law has been considered too simplistic or conservative. Conversely, deconstruction of state law as a means of generating its use for garnering social equality has been considered more relevant by not a few scholars. Unlike formalistic analysis of state law, deconstructionists have fundamentally been opposed to the legal political setting as has been shaped primarily since the 1967 war.

Formalistic adherents of state law have been engaged, especially since the mid-I 980 os and through the I990s and early 2000s, in intensive efforts to draft a written constitution, and they have extensively used litigation in the Supreme Court, expecting it to advance Aharon Barak's 'constitutional revolution', declaring laws as null and void in cases of brute contradiction to the essence of Israel as a 'Jewish and democratic' state.

Alternatively, critical thinkers of law and society have unveiled the socio-economic, cultural and political forces that have halted social equality through formal law, promoting false sociopolitical consciousness, and benefiting the Jewish upper-socio-economic echelons of society. Hence, critical scholars of law and society have asked which alternative legal orders are feasible to promote social justice. Unlike formalistic scholarship that has been aimed at constructing better legal codes, critical law and society scholars have pointed out how a specific type of Zionist ideology, motivated by exclusivist socio-economic and political interests, has shaped state law, while legalising hegemonic interests. Therefore, state law needed to be deconstructed, so as to become accessible to marginalised groups, and to empower oppressed and marginalised interests and identities, allowing for equal representation in the legal field and the public arena. The I995 self-proclaimed judicial policy of 'constitutional revolution' that allowed the Supreme Court to form a constitutional review and abolish the Knesset's laws, have further garnered social criticism from both left and right (Barzilai, 2003; Gavison et al., I990; Mautner, 2008; Sultany, 2012; Saban, 2005). While the Supreme Court has incited an ideology of extensive judicial engagement in political issues, and litigation has been a more prominent type of collective action in Israel (Barzilai, 2007; Dotan and Hofnung, 200I; Dotan, 2013), law and society critical scholars have devoted their attention to various sources of social inequalities, and explored the ways in which law is advancing and challenging those inequalities.

\subsection{Militarism and inequality}

The crucial enormity of the armed forces in Israeli society has been a prominent issue that has framed and generated legal rights and legal practices. The actual real legal status of Israeli citizens has largely been affected by their military service or its absence. Anti-militarist legal research has promoted the deconstruction of state law and has benefited from research that has explicated how the legal setting has sustained and advanced militaristic aspects and organisations of collective violence in Israeli society. The arrangements of compulsory military service alongside collective political exemptions, e.g. to Yeshiva students, and the relative absence of effective judicial review on military issues, problems in the enforcement of civilian control over the armed forces, the repercussions of the militarisation of Israeli society on the practical status of Israeli ArabPalestinians, and the scope of desirable obedience to military orders, as well as the preservation of socio-economic stratification due to the sanctification of military and national security needs, 
have been unveiled in research (Ram, 2006; Shachar, I98I; Sheleff, I989, I996; Barzilai, I996; BenEliezer, I998; Gans, I992; Gross, 2003; Hofnung, I996; Kremnitzer, I987, I989, I994; Kretzmer, 2002; Levy, 2004; Peleg, I995, 2004b; Simon, I994; Statman, I997).

Furthermore, critical scholarship has excavated injustices in compulsory military service, the origins of and justifications for conscientious objection to military service, severe infringements of human rights associated with the 1967 military occupation, the prominence of national security arguments in legislation and court rulings, and the immense weight of myths around national security in sustaining the legal ideology of the Jewish nation-state while causing injustices to nonJewish minorities. The normative ramifications of these studies have revealed that law as an agent of military power should be critically unveiled and reformed by virtue of civil justice.

\subsection{Feminist deconstruction and equality}

Scholarly interactions between feminist scholars and anti-militaristic scholars have sometimes been symbiotic. Feminist thinkers (Gerbi, I996; Lahav, I993b; Herzog, I999) have alluded to the intimate bond between militarism, patriarchy and law. They have argued that women have been marginalised through the masculinity of militaristic, male-oriented discourse in Israel.

Hence, patriarchy has been identified as a cause of social discrimination, and the legal setting that has formed, maintained and entrenched gender discrimination has been subjected to deconstruction, primarily through the publications of feminists who have applied sociopolitical, cultural and legal feminist theories to the Israeli justice system. State law has been identified as a prime agent of patriarchy, and demands for its deconstruction have been advanced through the studies of feminists, especially since the early I990s when legal feminism became more integrated into Israeli law faculties (Bilsky, I998; Dahan-Kalev, I995; Hacker, 200I, 2003; Kamir, I998, 2004; Lahav, I993a; Morag-Levine, I994; Shachar, I993, 200I; Shalhoub-Kevorkian, I999, 2000; Tirosh, 2005; Rimalt, 2002, 2007; Almog, 2008). They have striven to dismantle male-made law as a garrison of patriarchy. Through their studies of the legal process, legislation, court rulings, law enforcement, judicial review, institutional arrangements, family law, the practice of violence, ethnicity, and nationality, they have embarked on establishing more egalitarian alternative perspectives.

Liberal feminists studying law and society have recommended ways to reform existing state law and have underscored equal enforcement of legislation and regulation (Lahav, I993a; Raday, I998). In contrast, critical feminists have striven to examine the fundamental sociopolitical, economic and cultural causes of women's historical dependency upon and subjugation by men, which have led to systematic discrimination against women. Hence, social equality between men and women necessitates the deconstruction of legal ideologies, interests and principles of policy that underlie the prevailing patriarchal legal setting. Indeed, liberal jurisprudence in Israel has embedded, especially since the I990s, some reforms that have been based on more litigation around pay equity, affirmative action legislation, court rulings, and legislation to reduce the scope of sexual harassment, and to increase the advancement of women in the armed forces, including in battle units and as battle pilots in the air force, and the promotion of women in the labour market. Yet critical feminists have studied why and how these reforms have not significantly altered the basic structural discrimination against women (Bilsky, I998; Dahan-Kalev, I995; Hacker, 200I, 2003; Kamir, I998, 2004; Lahav, I993a; Morag-Levine, I994; Shachar, I993, 200I; Shalhoub-Kevorkian, I999, 2000; Tirosh, 2005; Rimalt, 2002, 2007; Almog, 2008).

Discrimination against homosexuals has been another issue that has garnered attention by Israeli law and society scholars. Most feminists who have studied law and society have been heterosexual (Barzilai, 2003), and they have often presumed the dominance of heterosexual ideology. Conversely, queer theories have underscored the pathologies of injustice embedded in the sociopolitical and legal dominance of heterosexual ideology. Legal deconstruction from a 
homosexual perspective has been required to allow for a better understanding of the ways in which heterosexual ideology has been perceived and practised in law as the 'normal state of affairs', and how in turn heterosexual ideology has justified explicit and implicit discrimination against homosexuals (Gross, I998; Harel, 2000; Spivak, 2006).

\subsection{Veiled voices: historical inequalities, language and hegemony}

Current injustices have been effected through the past. Law and society scholars have also contributed to a better understanding of legal histories of state law, legal practices and alternative hermeneutics. Traditionally, the legal histories of Israel were narrated through the autobiographies of judges and lawyers, biographies, archive material such as diaries, protocols and primary documents, and other secondary sources.

The research, publication and teaching of critical legal history are relatively new in Israel and, similarly to other fields in law and society scholarship, it has emerged through critical scholarship in the West, predominately in the US. Critical research of legal histories has been published by scholars who graduated from law schools, often with some complementary undergraduate or graduate education in history. Most of these graduates then attended leading universities, again mainly in the US, and were supervised by prominent legal historians, such as Morton J. Horwitz at Harvard Law School and Lawrence M. Friedman at Stanford Law School (Lahav, I993a; Harris, Kedar, Lahav and Likhovski, 2002; Likhovski, I998; Shamir, 2000)

They have looked at marginalised legal voices, mainly in Mandatary Palestine (I9I7-I948), and then unveiled marginalised cultural groups and minorities, primarily Muslim Arab-Palestinians. The history of the Supreme Court has also been a topic of more critical research, especially during its early years (Brun, 2008, 2014; Sagy, 2004), when the Court had to deal with injustices in Israel in its formative years. Thus, through these writings, we may identify the structural origins and boundaries of contemporary legal interpretations that have emerged as part of the national Jewish project, and the marginalisation of some types of legal hermeneutics. Accordingly, we may also explore economic sociopolitical sources and interests that are underlying the Israeli land regime and property law (Kedar, I998, 2001; Yiftachel, 2000).

Overall, due to critical studies of legal histories, we can trace the creation and costs of the dominant legal ideology and its historical ramifications in contemporary Israel. Rather than deliberating on one imagined unified history of law, this scholarship has generated various explorations of histories of law, and explicated how the formal legal setting has been constructed by the hegemonic Zionist elite, while marginalising other potential legal orders. Deconstructing state law and its ideology and interests via examining untold histories of communities and groups has enabled us to comprehend the essence of legal pluralism and the practices that have pointed to various legal normative orders, some of which were marginalised and suppressed following the establishment of Israel as a Jewish republic.

The studies cited above, with their focus on law and social equality, have reflected heterogeneous research projects embedded in additional critical disciplines. Critical sociological, economic, linguistic and political studies have explored Israel's hegemonic culture that has shaped state law and legal cultures (Mautner, I998, I999; Mautner et al., I998; Barak-Erez, 200I, 2002). Similarly, Marxist, neo-Marxist and post-Marxist scholars of Israeli law (Hirschl, I997, 2004; Peled, I992; Shafir and Peled, 2002; Bruner and Peled, 2000; Shamir, I990, I994, I996) have identified social class interests in the forming of judicial hegemony, citizenship and legal ideology mobilised through the legal profession. A similarly critical approach to the study of law and society has been published regarding the ascendancy of the liberal conception of private property, the private accumulation of wealth, and the decline of the representation of labour unions (Gross, I998; Holzman-Gazit, I997; Kedar, I998, 200I; Margalit, 2006; Mundlak, I998; Lobel, I998). Thus, a regulatory regime of egalitarian land allocation between Jews and Arabs has been suggested, as 
have new ways to empower employees through the construction of a more democratic and egalitarian labour environment.

Soaring socio-economic stratification and decreasing social welfare services have primarily endangered non-ruling communities, such as Arab-Palestinians and ultra-Orthodox Jews, who have been further marginalised in an intensively capitalised economy that for various reasons has not been receptive to these constituencies. Critical communitarian thinkers and students of localities and marginalised minorities have debated the ability of non-ruling communities and various localities to attain equality through state law and communal hermeneutics (Barzilai, 2003, 2005; Blank, 2004; Elbashan, 2003; Jabareen, 2000; Jamal, 2002, 2005; Migdal, 200I; Saban, 2002, 2004).

Language and law are inseparable, both as a means to attain justice and as a means to forestall it. Law is constituted through language, and it constructs language. The constitutive presentations of law and its enforcement are generated through language. While a more doctrinal reading of law may reduce language to formalities, more recent studies have used linguistic deconstruction of law in order to demonstrate its hidden national, cultural, sexual, economic, racial and ethnic interests that may cause discrimination and inequalities (Kamir, I998, 2004; Tirosh, 2005; Esmeir, 2004; Yovel, 200I).

Similarly, as part of the scholarly effort to deconstruct state law so as to promote more social justice, and halt injustices, students of criminal law and society have examined how national identities, ethnicity, gender and socio-economic dispositions may affect criminal prosecution, judicial decisions, punishment, policing and law enforcement among various segments of society. Some studies have revealed discrimination against Israeli Arab-Palestinians, through police behaviour towards the minority members (Hasisi, 2006; Kremnitzer, I989; Kremnitzer and Shapira-Ettinger, I999; Lavi, 2005; Shapira, I997; Salzberger, I996; Sebba, I999; Sheleff, I989, 2000; Gazal-Ayal and Kenan-Sulitzianu, 2010)

\subsection{A culture of litigation}

Not only state law and legal texts, but also lawyers as professional agents who may generate more equality have been subjected to critical research. Israel has had the highest number of lawyers per capita in the world among democracies (Barzilai, 2007). The lawyering profession itself has been under criticism since legal scholars have introduced crucial questions about its essence and aims (Shamir and Ziv, 200I). Some lawyers have been 'cause lawyers' (a term first coined by two prominent American scholars, Austin Sarat and Stuart Scheingold, I998, 2004), namely, they have attempted to promote the social interests of marginalised groups and promote equality. Yet most Israeli lawyers have been active in business and civil law for profit-making purposes, while only relatively few have devoted their time to human rights cases, and even fewer have acted as cause lawyers (Barzilai, 2007).

The level of litigation in Israel has been so intensive that it has replaced other avenues of potential public action, and has been used by both marginalised groups and elites to mobilise political interests (Dotan and Hofnung, 200I). Yet in summer 20I I, massive social protest in Israel showed that lawyers' effect on Israeli society may be in decline. The demonstrators and their elite leaders rejected the path of litigation that has failed to generate meaningful social change. Lawyers have also been unnecessary for social mobilisation due to the Internet and the ability to mobilise the masses through digital means (Almog and Barzilai, 20I4).

All of these studies have not only examined how litigation transforms issues from the private to the public sphere, and vice versa, but have also weighed the social costs and benefits of litigation to a democratic and egalitarian society. While litigation may mobilise resources for particular political social issues, and transform them to become salient public constitutional problems, it may also serve state power and its hegemonic ideology by eliminating or marginalising other avenues of 
collective action such as demonstrations and civil disobedience. Hence, as the above-cited research has argued, litigation has not necessarily incited more social equality.

\section{Conclusion}

This paper has systematically explicated how and why law and society scholars have narrated the place of law in politics and society, and the role of social political forces in law. Clearly, no one paper can wholly cover all the material that has been written and published by a large and dynamic community of Israeli scholars. Yet, relying on Hebrew, English and Arabic sources, I have tried to map some of the major issues that have characterised the scholarly debates and intellectual discourse, primarily critical questions on political power, the nation-state, law, rights discourse and equality.

On the one hand, major issues of research have reflected local predicaments and challenges vis-àvis Jewish Zionist nationalism in a bi-national setting. Local multiculturalism, and gender, ethnic, socio-economic, religious-secular and national divides have all affected, as was unveiled above, the scholarship of law and society writings. The 1967 military occupation, alongside the emergence of a neo-liberal capitalist economy, has generated a more critical outlook on the legal challenges embedded in sociopolitical, economic and cultural practices. The lack of success, or absence of interest, in resolving the Arab-Palestinian-Israeli conflict, and the fragmentation of the political partisan map in Israel, have incited more emphasis on the place of the Israeli Supreme Court, primarily sitting as a High Court of Justice, in public life as an important regulatory institution. This focus on the judicial power of the Court has resulted in even more frantic controversy on whether the Court has become too engaged in political affairs.

On the other hand, the developments and trends in Israeli academia, by and large, and within the field of law and society scholarship in particular, have been tightly linked to developments and trends in Western academia, predominantly the US. The rise of the politics of identity, and its reflections in more realist research on interactions between identities, institutions and cultures, has affected law and society studies in the Israeli context. Similarly, the influence of critical legal studies and post-Marxist concepts of law, underscoring how law may maintain and even advance power relations and socio-economic stratification, have touched upon Israeli scholars through their legal education and academic training. Local and more global types of understanding how to read and analyse law, particularly through a critical deconstructionist lens, have become integral parts of the ways that knowledge of law and society in context has been produced and published.

\section{References}

AkzIN, Benjamin (I965) Hatsaat Huka Le'Yisrael [A Constitution Draft for Israel]. Tel Aviv: Bnai Brith [Hebrew].

AkzIN, Benjamin (I966) Sugiot Be'Mishpat U'bemedinaut [Issues in Law and Politics]. Jerusalem: Magnes Press [Hebrew].

AKzin, Benjamin (I968) 'Ha'Piramidot Shel Normot U'Mosadot' [The Pyramids of Norms and Institutions], in Benjamin Aktzin (ed.), Torat Ha'Mishtarim [The Theory of Regimes]. Jerusalem: Akademon, I20-I43. [Hebrew].

AL-HAJ, Majid (1995) Education, Empowerment and Control: The Case of Arabs in Israel. Albany, NY: State University of New York Press.

ALMOG, Shulamit (2008) Abandoned Women. Tel Aviv: Defense Ministry.

ALMOG, Shulamit and BARzILAI, Gad (2014) 'Social Protest and the Absence of Legalistic Discourse: In

the Quest of New Language of Dissent', International Journal for the Semiotics of Law 27(4): 735-756. ALon, Menachem (1973) The Hebrew Law. Jerusalem: Magnes Press [Hebrew]. 
BARAK, Aharon (I998) 'Hamishim Shnot Mishpat Be'Yisrael' [Fifty Years of Law in Israel]. Alpaim r6: 36-44 [Hebrew].

BARAK, Aharon (2004) Shofet Be'hevra Demokratit [The Judge in a Democracy]. Haifa: University of Haifa Press [Hebrew].

BARAK, Aharon (2006) The Judge in a Democracy. Princeton, NJ: Princeton University Press.

BARAK-EREZ, Daphne (200I) 'Collective Memory and Judicial Legitimacy: The Historical Narrative of the Israeli Supreme Court', Canadian Journal of Law and Society I6: 93-I I2.

BARAK-EREZ, Daphne (2002) 'The Primaries System and Its Constitutional Effect: Where is the Revolution?', Theoretical Inquiries in Law 3: 197-206.

barzILAI, Gad (I996) Wars, Internal Conflicts, and Political Order: A Jewish Democracy in the Middle East. Albany, NY: State University of New York Press.

BARZILAI, Gad (1998) 'Political Institutions and Conflict Resolution: The Israeli Supreme Court and the Peace Process', In Ilan Peleg (ed.), The Middle East Peace Process: Interdisciplinary Approaches. Albany: State University of New York Press, 87-106.

BArzILAI, Gad (2003/2005) Communities and Law: Politics and Cultures of Legal Identities. Ann Arbor, MI: University of Michigan Press.

BarziLAI, Gad (2005) 'The Evasive Facets of Law: Litigation as Collective Action', Adalah Review.

BARzILAI, Gad (2007) 'The Ambivalent Language of Lawyers: Between Liberal Politics, Economic Liberalism, Silence and Dissent', In Malcolm Feeley, Terry Halliday and Lucien Karpik (eds), Fighting for Political Freedom. Oxford: Hart, 247-280.

BARZILAI, Gad and PELEG, Ilan (2009) 'Engineering the Law and Justice Deconstruction: Ideologies of

Knowledge in Law and Politics in Israel and Beyond', Journal of Comparative Law 4: 205-227.

Barzilai, Gad, Segal, Zeev and yuchtman-YaAR, Efraim (1994) The Israeli Supreme Court and the Israeli

Public. Tel Aviv: Tel Aviv University Press.

BEN-ELIEZER, Uri (I998) The Making of Israeli Militarism. Bloomington/Indianapolis, IN: Indiana University Press.

BILSKY, Leora (I998) 'Giving Voice to Women: An Israeli Case Study', Israel Affairs 3(2): 47-79.

BLANK, Yishai (2004) 'The Location of the Local: Local Government Law, Decentralization and

Territorial Inequality in Israel', Mishpatim 34: 197-299 [Hebrew].

BRUN, Nathan (2008) Judges and Jurists in Eretz Yisrael. Jerusalem: Magnes Press [Hebrew].

BRUN, Nathan (2014) Law, Desires, and Politics: Judges and Jurists in the End of the Mandatory Period and the

Establishment of Israel. Tel Aviv: Stimatzky Publishing House [Hebrew].

BRuner, Josse and Peled, Yoav (2000) 'Culture Is Not Enough: A Democratic Critique of Liberal

Multiculturalism', in Shlomo Ben-Ami, Yoav Peled and Alberto Spektorovski (eds), Ethnic

Challenges to the Modern Nation-State. Basingstoke: Macmillan, 65-92.

CARmi, Naama (2003) The Law of Return: Immigration Rights and Their Limits. Tel Aviv: Tel Aviv University Press.

Dahan-Kalev, Henriette (I995) 'The Right to Experience a Revolt: Between Oppression and Empowerment', Noga 28: 22-24 [Hebrew].

dotan, Yoav (1999) 'Judicial Rhetoric, Government Lawyers, and Human Rights', Law and Society Review 33(2): 319-363.

DOtan, Yoav (2013) Lawyering for the Rule of Law: Government Lawyers and the Rise of Judicial Power in Israel. New York: Cambridge University Press.

Dotan, Yoav and hofnung, Menachem (200I) 'Interest Groups in the High Court of Justice: Measuring

Success in Litigation and in Out-of-Court Settlements', Law and Policy 23(I): I-27.

elbashan, Yuval (2003) 'Foreigners in the Hall of Justice', Panim 26: 4-I I [Hebrew].

ENGEL, David and MUNGER, Frank (2003) Rights of Inclusion: Law and Identity in the Life Stories of Americans with Disabilities. Chicago, IL: University of Chicago Press.

eSmeIR, Samra (2004) 'Law, History, Memory', Social Text 2 I(2): 25-48. 
FISHeR, W. William and horwitz, J. Morton (eds) (I993) American Legal Realism. Oxford: Oxford University Press.

GANs, Haim (1992) Philosophical Anarchism and Political Disobedience. Cambridge: Cambridge University Press.

GAvison, Ruth (I999a) 'Jewish and Democratic? A Rejoinder to the "Ethnic Democracy” Debate', Israel Studies 4(I): 44-72.

Gavison, Ruth (I999b) Israel as Jewish and Democratic State: Tensions and Chances. Tel Aviv: Hakibutz Ha'Meuchad [Hebrew].

GAvison, Ruth and HACKER, Daphne (2000) The Arab-Israeli Rift - A Reader. Jerusalem: Israel Democratic Institute.

gavison, Ruth, kremnitzer, Mordechai and Dotan, Yoav (I990) Aktivism Shiputi [Judicial Activism]. Jerusalem: Magness Press [Hebrew].

GazAl-Ayal, Oren and kenan-sulitzianu, Raanan (2010) 'Let My People Go: Ethnic In-Group Bias in Judicial Decisions', Journal of Empirical Research 7(3): 403-423.

GERBI, Iris (I996) Maamad Ha'Eisha BaHevra Ha'Yisraelit V'Sheirut Nashim Batsava[The Status of Woman in Israeli Society and Female Service in the Military]. Tel Aviv: Papirus Press [Hebrew].

Gross, Aeyal (I998) 'Kenian Ke’Zchut Hukatit Ve’Hok Yesod Kvod Ha’Hadam Ve’Heruto’ [Property as a Constitutional Right and Basic Law: Human Dignity and Liberty], Eyunei Mishpat [Tel Aviv University Law Review] 2 I(3): 405-447 [Hebrew].

GRoss, Oren (2003) 'Chaos and Rules: Should All Responses to Violent Crises Be Constitutional?', Yale Law Journal I I 2: IOI I-I I34.

HACKER, Daphna (200I) 'Single and Married Women in the Law of Israel - A Feminist Perspective', Feminist Legal Studies 9(I): 29-56.

HACKER, Dafna (2003) “'Hemaut”, "Habaut”, U'Mishpat'['Motherhood', 'Fatherhood' and Law]. Unpublished $\mathrm{PhD}$ dissertation, Tel Aviv University [Hebrew].

HAReL, Alon (2000) 'The Rise and Fall of the Israeli Gay Legal Revolution', Columbia Human Rights Law Review 3I: 443-47I.

harris, Ron, Kedar, Alexandre, LAHav, Pnina and likhovski, Assaf (eds) (2002) The History of Law in a Multi-cultural Society. Aldershot: Ashgate.

HAsIsI, Badi (2006) Policing and Citizenship in a Deeply Divided Society: Police-Minority Relations in Israel. Unpublished PhD dissertation, Department of Sociology, University of Haifa.

HERzoG, Hanna (I999) Gendering Politics: Women in Israel. Ann Arbor, MI: University of Michigan Press. HIRSCHL, Ran (I997) 'The Constitutional Revolution and the Emergence of a New Economic Order in Israel', Israel Studies 2(I): I36-I 55.

HIRSCHL, Ran (2004) Towards Juristocracy: The Origins and Consequences of the New Constitutionalism. Cambridge, MA: Harvard University Press.

Hofnung, Menachem (1996) Democracy, Law, and National Security in Israel. Aldershot: Dartmouth. holzman-Gazit, Yifat (I997) Private Property, Culture and Ideology: Israel's Supreme Court and the Jurisprudence of Land Expropriation. Unpublished PhD dissertation, Stanford University. JABAREEn, Hassan (2000) 'Toward a Critical Palestinian Minority Approach: Citizenship, Nationalism and Feminism in Israeli Law', Plilim - Israel Journal of Criminal Law I I: 53-I43 [Hebrew]. JAmal, Amal (2002) 'Beyond "Ethnic Democracy": State Structure, Multi-Cultural Conflict and Differentiated Citizenship in Israel', Journal of New Political Science 24(3): 4I I-43 I.

Jamal, Amal (2005) 'On the Morality of Arab Collective Rights in Israel', Adalah Newsletter. Online: 〈http://www.adalah.org/uploads/oldfiles/newsletter/heb/apro5/ar2.pdf〉 [Hebrew].

KAMIR, Orit (I998) 'Ha’Retorika Shel Baalut Bachok Ha’Plili Ha'Yisraeli Ve'Hashivuto Ha’Tarbutit’ [The Rhetoric of 'Husbanding' in Israel's Penal Code and Its Cultural Significance], Plilim - Israel Journal of Criminal Law 7: I2 I-I60 [Hebrew]. 
KAMIR, Orit (2004) Shaela Shel Kavod: Yisraeliut Ve'Kvod Ha'Hadam [Israeli Honor and Dignity: Social Norms, Gender Politics and the Law]. Jerusalem: Carmel.

KeDAR, Alexander (I998) 'Majority Time, Minority Time: Land, Nation, and the Law of Adverse

Possession in Israel', Eyunei Mishpat [Tel Aviv University Law Review] 2 I(3): 665-746 [Hebrew]. KEDAR, Alexander (200I) 'The Legal Transformation of Ethnic Geography: Israeli Law and the

Palestinian Landholder I948-I967', Journal of International Law and Politics 33(4): 923-1000. KLINGHOFfER, Hans (1963) Megilat Zchuiot Ha'Yesod Shel Haadam: Hatzaat Hcok [The Constitution of Basic Human Rights: A Bill]. Jerusalem: The Liberal Party, The Israeli Parliament-Knesset [Hebrew]. KREMnitzer, Mordechai (I987) 'Hcaninat Ha’Shin Bet: Ha’im Bagatz Avar et Ha'Mivchan?' [The Amnesty of the Shin Bet: Did the High Court of Justice Pass the Test?], Eyunei Mishpat [Tel Aviv University Law Review] I 2: 595-620 [Hebrew].

Kremnitzer, Mordechai (I989) 'The Landau Commission Report: Was the Security Service Subordinated to the Law or the Law to the Security Service?', Israel Law Review 23: 2 I6-279. KREMNITZER, Mordechai (I994) 'The Expelling of the Deportation: A Few Notes on Decisions Regarding

Deportation, the High Court of Justice, Law, Politics and Morality' [Hebrew], Plilim - Israel Journal of Criminal Law 4: 17-38 [Hebrew].

KREMnitZer, Mordechai, KRETZMer, David and Benish, Avishai (2002) Uhkei Ha'Yesod Ke'Tashtit Le'Huka

[Basic Laws as an Infrastructure for a Constitution]. Jerusalem: Israel Democracy Institute [Hebrew]. KREMnitzer, Mordechai and shapira-ETtinger, Keren (I999) 'Politics and Law: Jerusalem Mix', Plilim -

Israel Journal of Criminal Law 8: I95-227.

KRETZMER, David (I990) The Legal Status of Arabs in Israel. Boulder, CO: Westview Press.

KRETZMER, David (2002) The Occupation of Justice: The Supreme Court of Israel and the Occupied Territories.

Albany, NY: State University of New York Press.

Lahav, Pnina (I993a) 'The Knesset Debate over the Law of Woman's Rights Equality', Zemanim 46: I49-I59 [Hebrew].

LAHAV, Pnina (I993b) 'A Barrel without Hoops: The Impact of Counter-Terrorism on Israel's Legal

Culture', Cardozo Law Review I0: 529-559.

LAVI, Shai (2005) 'Imagining the Death Penalty in Israel: Punishment, Violence, Vengeance and

Revenge', in Austin Sarat and Christian Boulinger (eds), The Cultural Lives of the Death Penalty.

Stanford, CA: Stanford University Press, 219-230.

LEvy, Yagil (2004) Another Military for Israel: Materialist Militarism in Israel. Tel Aviv: Yedioth Aharonot [Hebrew].

Liknovski, Assaf (I998) 'The Invention of "Hebrew Law” in Mandatory Palestine', American Journal of

Comparative Law 46: 339-373.

LOBEL, Orly (1998) Mishpat Ha'Avoda [Labor Law]. Tel Aviv: Ethics Press [Hebrew].

margalit, Avital (2006) 'The Value of Home Ownership', Theoretical Inquiries in Law 7: 467-492.

MAUTnER, Menachem (I998) 'Sechel Yashar, Legitimatzia, Ve’Kefia: Al Shoftim Ke’Mesaprei Sipurim'

[Common Sense, Legitimacy, and Coercion: On Judges as Story Tellers], Plilim - Israel Journal of

Criminal Law 7: I I-76 [Hebrew].

MAUTNER, Menachem (I999) 'Batei Din Rabbaniim Be’Netivot' [Rabbinical Courts in Netivot], Teoria

Ve'Bikoret [Theory and Practice] I2/I3: 467-475 [Hebrew].

MAUTNER, Menachem (2008) Law and Culture in Israel at the Outset of the 2 Ist Century. Tel Aviv: Am Oved.

mautner, Menachem, sagie, Avraham and shamir, Ronen (eds) (I998) Rav Tarbutiut Be'hevra Yeudit

Ve'Democratit [Multiculturalism in a Jewish and Democratic State]. Ramot: Tel Aviv University Press [Hebrew].

MIGDAL, Joel (200I) Through the Lens of Israel: Explorations in State and Society. Albany, NY: State University of New York Press. 
MORAG-LEVINE, Noga (1994) 'Abortion in Israel: Community, Rights, and the Context of Compromise', Law and Social Inquiry I9(2): 313-335.

MUNDLAK, Guy (I 998) 'The New Labor Law as a Social Text: Reflections on Social Values in Flux', Israel Studies 3(2): II9-I58.

Peled, Yoav (I992) 'Ethnic Democracy and the Legal Construction of Citizenship: Arab Citizens of the Jewish State', American Political Science Review 86(2): 432-443.

PELEG, Ilan (I995) Human Rights in the West Bank and Gaza: Legacy and Politics. Syracuse, NY: Syracuse University Press.

PELEG, Ilan (2004a) 'Israel as "Jewish and Democratic" - Revising the Sacred Formula', Reconstructionist 68(2): I6-25.

PELEG, Ilan (2004b) ‘Jewish-Palestinian Relations in Israel: From Hegemony to Equality?', International Journal of Politics, Culture \& Society I7(3): 4I5-435.

RADAY, Frances (I998) 'The Concept of a Gender Equality in a Jewish State', in Shimon Shetreet (ed.), Women in Law. London: Kluwer, 47-59.

RAm, Uri (2006) The Time of the 'Post' Nationalism and the Politics of Knowledge in Israel. Tel Aviv: Resling. Rimalt, Noya (2002) 'Separation between Men and Women as Gender Discrimination', Papers of Law 3: I99-240 [Hebrew].

RIMALt, Noya (2007) 'Women in the Sphere of Masculinity: The Double-Edged Sword of Women's Integration in the Military', Duke Journal of Gender, Law \& Policy I4(2): I097-I I I9.

rouhana, Nadim (1997) Palestinian Citizens in an Ethnic Jewish State. New Haven, CT: Yale University Press.

Rubinstein, Amnon (1969-2005) Ha'Mishpat Ha'Konstitutzioni Shel Medinat Yisrael [Israel Constitutional Law]. Tel Aviv: Shocken Publishing House [Hebrew].

SABAN, Ilan (2002) 'The Status of Arabic in Israel: Reflections on the Power of Law to Produce a Social Change', Israel Law Review 36(2): 5-39.

Saban, Ilan (2004) 'Minority Rights in Deeply Divided Societies: A Framework for Analysis and the Case of the Arab Palestinian Minority in Israel', New York University Journal of International Law and Politics 36: 885-1003.

SABAN, Ilan (2005) 'The Israeli Supreme Court and the Arab-Palestinian Minority', Mishpat U'Mimshal 8: $23-27$.

SAGY, Yair (2004) 'For the Administration of Justice: On the Establishment of High Court of Justice of Israel', Eyunei Mishpat [Tel Aviv University Law Review] 28: 225-297 [Hebrew].

SAlzberger, Eli (I996) 'The Attorney General and the Doctrine of Separation of Powers', Plilim - Israel Journal of Criminal Law 5: I49-I72 [Hebrew].

Sarat, Austin and scheingold, Stuart (1998) Political Commitments and Professional Responsibilities. Oxford: Oxford University Press.

Sarat, Austin and scheingold, Stuart (2004) Something to Believe In: Politics, Professionalism, and Cause Lawyering. Stanford, CA: Stanford University Press.

SEBBA, Leslie (I999) 'The Creation and Evolution of Criminal Law in Colonial and Post-Colonial Societies', Crime, History and Societies 3: 7I-90.

SHACHAR, Ayelet (I993) 'Miniuoto Shel Ha'Chok: Ha’Siach Ha'Mishpati Benose Ha'Ones' [The Sexuality of the Law: The Legal Discourse Concerning Rape]. Eyunei Mishpat [Tel Aviv University Law Review] I8: I59-200 [Hebrew].

SHACHAR, Ayelet (200I) Multicultural Jurisdictions: Cultural Differences and Human Rights. Cambridge:

Cambridge University Press.

SHACHAR, Yoram (I98I) 'The Trials of Gadi Elgazi', Israel Yearbook of Human Rights I2: 2 I4-259.

SHAFIR, Gershon and PELED, Yoav (2002) Being Israeli: The Dynamics of Multiple Citizenship. Cambridge:

Cambridge University Press. 
Shalhoub-Kevorkian, N. (I999) 'Law, Politics, and Violence against Women: The Case-Study of Palestinian-Israelis', Law and Policy 2 I (2): I89-2 I I.

ShalHoub-Kevorkian, N. (2000) 'The Efficacy of Israeli law in Preventing Violence within Palestinian

Families Living in Israel', International Review of Victimology 7: 47-66.

SHAmir, Ronen (I990) 'Landmark Cases and the Reproduction of Legitimacy: The Case of Israel's High

Court of Justice', Law and Society Review 24: 78I-805.

SHAMIR, Ronen (1994) 'Discretion as Judicial Power', Theory and Criticism 5: 7-23 [Hebrew].

SHAMIR, Ronen (I 996) 'Suspended in Space: Bedouins under the Law of Israel', Law and Society Review 3O(2): $23 \mathrm{I}-257$.

Shamir, Ronen (2000) The Colonies of Law: Colonialism, Zionism, and the Law in Early Palestine.

Cambridge: Cambridge University Press.

SHAmir, Ronen and ziv, Neta (200I) 'State-Oriented and Community-Oriented Lawyering For A Cause:

A Tale of Two Strategies', in A. Sarat and S. Scheingold (eds), Cause Lawyering and the State in the

Global Era. New York: Oxford University Press, 287-304.

ShaprRA, Amos (1983) 'Judicial Review without a Constitution: The Israeli Paradox', Temple Law Quarterly 56: 405-462.

SHAPIRA, Amos (I 993) 'Why Israel Has No Constitution - But Should, and Likely Will, Have One', Saint

Louis University Law Journal 37: 283-290.

SHAPIRA, Amos and BRACHA, Baruch (1972) 'The Constitutional Status of Individual Freedoms', Israel

Yearbook on Human Rights 2: 2 I I-246.

SHAPIRA, Ron (I997) 'Disciplinary Measures against Minors as Justification in Criminal Law', Israel Law

Review 30: I6I-I70.

SHELEFF, Leon (I 989) Kol Ha'Kavod [The Voice of Honor]. Tel Aviv: Ramot - Tel Aviv University [Hebrew]. SHELEFF, Leon (1996) Marut Ha'Mishpat U'Maut Ha'Mishtar [Legal Authority and the Essence of the Regime].

Tel Aviv: Papirus Press [Hebrew].

ShelefF, Leon (2000) The Future of Tradition. London: Frank Cass.

SImon, Dan (I994) 'The Demolition of Homes in the Israeli Occupied Territories', Yale Journal of International Law ig(I).

Sмоона, Sammy (I990) 'Minority Status in Ethnic Democracy: The Status of the Arab Minority in

Israel', Ethnic and Racial Studies I3(2): 389-4I3.

sмоона, Sammy (1997) 'Ethnic Democracy: Israel as an Archetype’, Israel Studies 2: 198-24I.

sмоона, Sammy (1999) Autonomy for Arabs in Israel? Givat Haviva: Institute for Israeli Arab Studies

[Hebrew].

SPIVAK, Dori (2006) 'Freedom of Speech in First Body', in Michael Birnhack (ed.), Be Quiet! Someone is

Speaking: The Legal Culture of Freedom of Speech in Israel - Studies in Law, Society, and Culture. Tel

Aviv: Ramot - Tel Aviv University, 425-432.

statman, Daniel (I997) 'Jus in Bello and the Intifada', in Tomis Kapitan (ed.), Philosophical Perspectives

on the Israeli-Palestinian Conflict. New York: M. E. Sharp, I33-I56.

Statman, Daniel and SAPIR, Gideon (2014) State and Religion in Israel: A Philosophical and Legal Analysis.

Haifa: University of Haifa Press.

STERN, Yedidia and RAvitzki, Aviezer (2007) Things and Parts of Things: On the Judaism of a Democratic

State. Jerusalem: Israel Democratic Institute.

sultany, Nimer (2012) 'The Making of an Underclass: The Palestinian Citizens of Israel', Israel Studies

Review 27(2): 190-200.

Tirosh, Yofi (2005) 'Beekvot Ha'Haava Ve’ Haprat Le’Marta Nussbaum' [Following the Love and the

Individual of Martha Nussbaum], Law, Society and Culture 2: 433-474.

YIFTACHeL, Oren (2000) 'Landed Power: The Making of the Israeli Land Regime', Theory and Criticism.

YIFTACHeL, Oren (2006). Ethnocracy: Land, and the Politics of Identity Israel/Palestine. Philadelphia, PA:

University of Pennsylvania Press. 
YOVEL, Jonathan (200I) 'Lingual Violence', Plilim - Israel Journal of Criminal Law IO: 24I-275 [Hebrew]. zAMIR, Itzhak (I993a) 'Ha'bikoret Ha'shiputit Al Hakikat Hukim' [The Judicial Review Over the Legality of Laws], Mishpat U'Mimshal [Law and Government] I: 395-4Io [Hebrew].

ZAmir, Itzhak (I993b) Sefer Klinghoffer Al Ha'Mishpat Ha'Tziburi [Klinghoffer's Book on Public Law]. Jerusalem: Hari Sakker Institute for the Research of Legislation and Comparative Law [Hebrew]. ZAMIR, Itzhak, with RUBInstein, Amnon and GUY-RON, Yoram (200I) Doch Ha'Vaada Le'Sidrei Ha'Bechira Shel Shoftim [The Report of the Committee for Procedures of Judicial Nominations]. Jerusalem: Ministry of Justice [Hebrew]. 